Click www.researchjournal.co.in/online/subdetail.html to purchase.

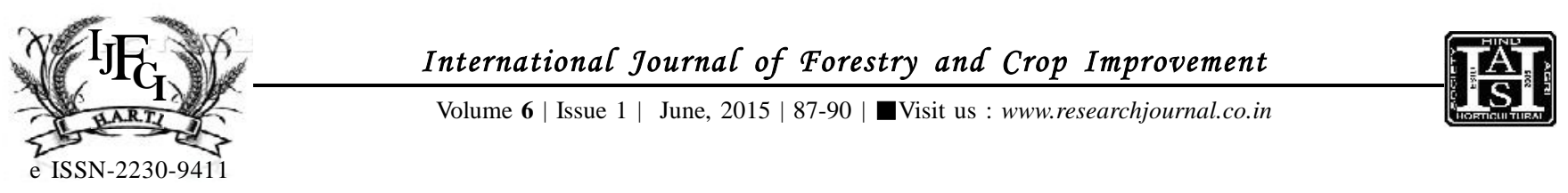

A CaSe Study

DOI: $10.15740 / \mathrm{HAS} / \mathrm{IJFCI} / 6.1 / 87-90$

\title{
Evaluation of biochemical changes during the storage of poultry composts for effective land application
}

\author{
M. Prasanthrajan, S. Shalini, T. Balaji and P. VeERAmani
}

\begin{abstract}
An incubation experiment was conducted to assess the storability of poultry droppings compost for effective utilization and field application. In general, the nutrient content of the compost will vary depending upon the quantity and nutrient content of the manure, age of the compost and the method of storage. In our present study, we found that the storage of poultry droppings under normal condition did not influence the $\mathrm{pH}$ of the compost in the first 30 days but a slight reduction in $\mathrm{pH}$ ( 0.1 to 0.2 ) was observed between $30^{\text {th }}$ day and $45^{\text {th }}$ day. The Electrical Conductivity (EC) of the stored compost was increased but the level of increase was not exceeded $0.02 \mathrm{dS} \mathrm{m}$. A slight increase in total nitrogen content was recorded during storage of poultry compost and this might be due to moisture loss and reduction in volume. A slight decrease in total phosphorus and total potassium was also recorded in the stored compost during $75^{\text {th }}$ and $90^{\text {th }}$ day of storage. The microbial population was high between $30^{\text {th }}$ and $45^{\text {th }}$ day of storage. Compost contained a relatively large amount of micro-organisms associated to organic nitrogen mineralization which might have altered the chemical properties. There was no much variation in the nutrient status of the compost during first 45 days of storage and hence the poultry compost can be applied to land within 45 days after its maturity to derive maximum benefits.
\end{abstract}

KEY WORDS : Poultry compost, Storage, Biochemical changes

HOW TO CITE THIS ARTICLE : Prasanthrajan, M., Shalini, S., Balaji, T. and Veeramani, P. (2015). Evaluation of biochemical changes during the storage of poultry composts for effective land application. Internat. J. Forestry \& Crop Improv., 6 (1) : 87-90.

Article Chronical : Received : 12.03.2015; Accepted : 30.05.2015

MEMBERS OF RESEARCH FORUM

Address of the Correspondence : M. PRASANTHRAJAN, Agricultural Research

Station, Virinjipuram, VELLORE (T.N.) INDIA Email: prasanth_phd@yahoo.co.in

Address of the Coopted Authors : S. SHALINI, T. BALAJI AND P. VEERAMANI, Department of Chemistry, Nirmala College for Women, COIMBATORE (T.N.) INDIA

ADD. CHANGE :- T. BALAJI ANd P. VEERAMANI, Agricultural

Research Station, Virinjipuram, VELLORE (T.N.) INDIA 